\title{
Growth parameters and density variation of a queen conch, Strombus gigas (Neotaenioglossa: Strombidae), population from Xel-Ha park, a marine protected area
}

\author{
Erick Baqueiro Cárdenas ${ }^{1} \&$ Dalila Aldana Aranda ${ }^{2}$ \\ 1. Instituto Tecnológico Superior de Champotón. Carretera Champotón-Isla Aguda Km 2, Colonia el Arenal, Champotón, \\ Camp. 24400, Mexico; ebaqueiro@gmail.com \\ 2. Centro de Investigación y Estudios Avanzados del Instituto Politécnico Nacional, Unidad Merida antigua carretera a \\ Progreso Merida Yucatán Mexico; daldana@mda.cinvestav.mx
}

Received 25-II-2013. C Corrected 20-VII-2013. Accepted 22-VIII-2013.

\begin{abstract}
The queen conch, Strombus gigas, is a gastropod of commercial importance in the Caribbean. Population studies are based on size frequency analysis, using either length or weight parameters for the whole live organism. This contribution used mark-recapture data to estimate the Von Bertalanffy equation parameters and population number variation within a non harvest population from a protected area, to clarify the biometric parameters that better suit for the whole population, or for the juvenile and adult fractions. Conchs from XelHa Park were monthly sampled from November 2001 to August 2005. Every conch found was measured and marked with a numbered tag that identified month and locality; and monthly abundance was estimated with Jolly's method. Length, lip thickness and weight increments were used to estimate the Von Bertalanffy growth equation parameters with Appeldoorn's subroutine of FISAT program. The population number varied through the study, with a minimum of 49 in April 2003 and maximum of 9848 during June 2005. Conchs make only temporary use of Xel-Ha cove. Shell length gave the best fit for the juvenile fraction: $\mathrm{L} \infty=251, \mathrm{~K}=0.3, \mathrm{C}=0.8$ $\mathrm{Wp}=0.3$; and lip thickness for adults: $\mathrm{L} \infty=47.78, \mathrm{~K}=0.17, \mathrm{C}=0.1, \mathrm{Wp}=0.86$, while, the whole population was better represented by weight: $\mathrm{L} \infty=3850, \mathrm{~K}=0.36, \mathrm{C}=0.8, \mathrm{Wp}=0.3$. A maximum age of 19 years was estimated from the population. Natural mortality was 0.49 /year for juveniles and 0.29 year for adults. There were two pulses of recruitment: fall-winter and summer. It is concluded that population studies from length frequency data, should be analyzed independently in two groups, shell for the juvenile fraction and lip thickness for the adult fraction, or if it is not possible to analyze the population fractions separately, weight should be used to avoid miss calculation of the age structure. Rev. Biol. Trop. 62 (1): 45-57. Epub 2014 March 01.
\end{abstract}

Key words: conch, growth, population parameters, marine protected area, Caribbean, MPA.

The queen conch Strombus gigas Linneaus, 1758 is a gastropod of economic importance in the Caribbean, with a distribution ranging from Venezuela to Florida and the Bahamas, including the lesser and mayor Antilles. Due to the high fishing pressure that is exerted upon its populations, most stocks have been reduced to levels where the population can no longer recover, and commercial fishing is no more feasible (Appeldoorn 1994a). Consequently, $S$. gigas has been included in the Convention on
International Trade in Endangered Species of Wild Fauna and Flora (CITES) since 1992, and in 1994, it was added to the International Union for the Conservation of the Nature's Red List.

Nowadays, conch populations from Honduras, Belize, Nicaragua and Dominican Republic are reported to be over exploited (FAO 2009). In Mexico S. gigas, populations have also been severely reduced (Perez Perez \& Aldana Aranda, 2000, Basurto, Basurto, Cadena, Escobedo, Fernández \& Figueroa, 2005 
Chávez \& Constanza-Mora, 2009, Balán-Dzul \& de Jesús-Navarrete, 2011), and urgent management policies are required.

Along the Caribbean, different management strategies are used, and the most common is the protection of the reproductive stocks or populations in recovery, through the establishment of closed areas to fishing activities, and the Marine Protected Areas (MPA) (Appeldoorn 1994a, Aldana Aranda, Baqueiro Cárdenas \& Manzanilla Naim, 2003).

To establish adequate strategies for population management and recovery, basic biological information is imperative. For this species, different studies have been made, and growth parameters are routinely assessed from shell-length-frequency analysis, which is acceptable for the Queen conch for the first four years of life, or until animals reach sexual maturity, when length growth ceases, and the characteristic flared lip is formed. Once maturity is reached, growth in length stops and growth can only be checked from lip thickness and weight increments (Alcolado 1976, Appeldoorn 1994b). Therefore, the use of shell length fails to estimate the growth parameters for the adult fraction of the populations. The objective of this contribution was to use mark recapture data obtained from a protected $S$. gigas population, to evaluate the most adequate biometric parameter to be used when studying natural populations.

\section{MATERIALS AND METHODS}

Sampling area: Xel-Ha Park is located within the Mesoamerican reef system. It is a cove on the East coast of the Yucatan Peninsula, $20^{\circ} 15^{\prime} 54^{\prime \prime} \mathrm{N}-87^{\circ} 24^{\prime} 08^{\prime \prime}$ W (Fig. 1). Communication to the Caribbean Sea is through a $70 \mathrm{~m}$ wide mouth extending $800 \mathrm{~m}$ inland with a total area of $14 \mathrm{Ha}$. The climate in the region is hot subhumid, with dominant rains during summer (June to September). Average rain fall is $2500 \mathrm{~mm}$ a year with a total evaporation of $2300 \mathrm{~mm}$. Mean annual temperature is $24.9^{\circ} \mathrm{C}$.

For this study, the cove was divided into three sections from the mouth connecting to the sea "La Bocana", inward, the "Centro" or central zone, and "La Cueva" or inner section of the cove. The principal difference between areas is the effect of underground fresh water runoff, which runs into La Cueva section,

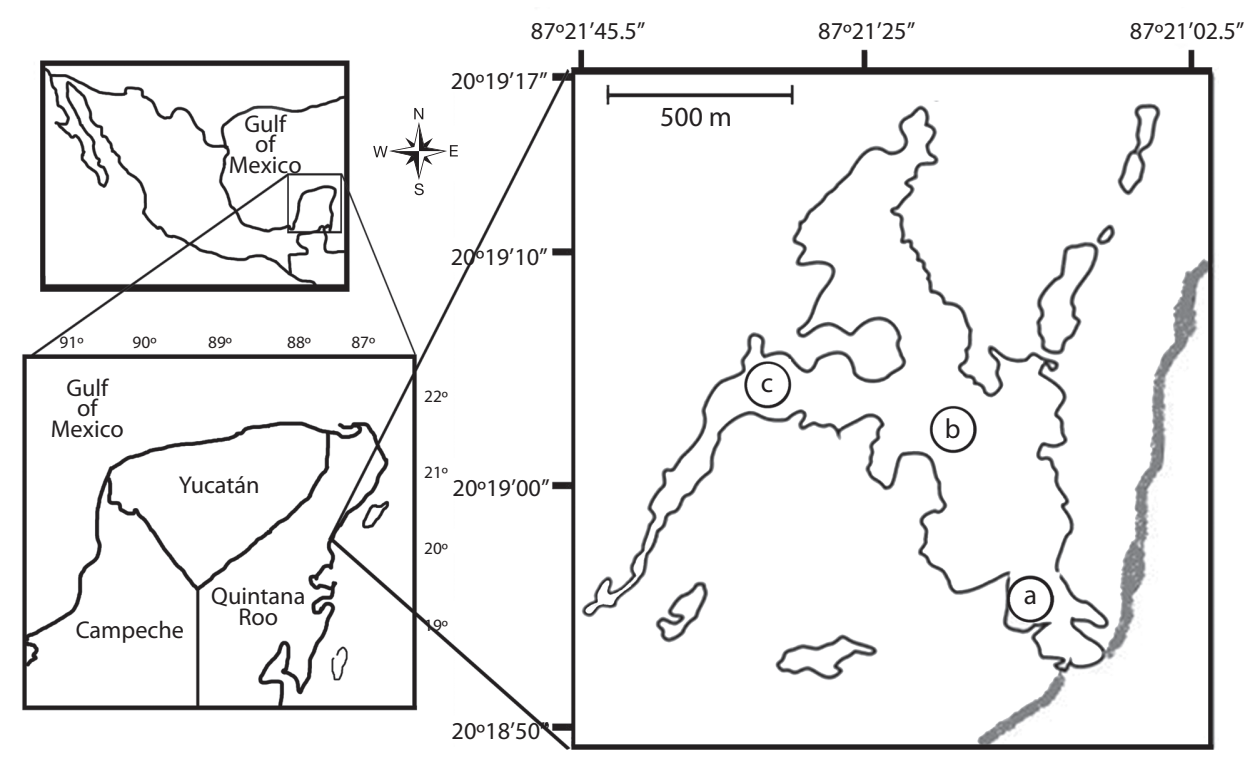

Fig. 1. Marine protected area of Xel-Ha Park, Quintana Roo, Mexico. Sampling stations: A, La Bocana; B, Centro; C, La Cueva. 
with increasing salinity towards La Bocana. The sediment type also changes inward from La Bocana, from sand to muddy-sand in the central part and sandy-mud in La Cueva. The presence and type of vegetation also has a significant difference between areas; in $\mathrm{La}$ Bocana, the prevailing vegetation is made up of macroalgaes like Halimeda sp., Ulva sp., Acetabularia sp., Caulerpa sp. as the most conspicuous. Whereas, in the Central section is covered by patches of Syringodium sp. and Thalassia sp.; La Cueva has no fixed vegetation, but decaying land vegetation as mangrove leafs are frequent.

Sampling strategies: Water quality parameters like temperature, salinity and dissolved oxygen were taken from bottom waters at La Bocana, Centro and La Cueva stations, with a YSI-50 multi-parameter water analyzer, for all the study period.

Mark-recaptured data started in November 2001 and continue in a monthly basis until October 2005; nevertheless, weather conditions prevented sampling some months. The survey was made by three free divers following a prefixed pattern of transects $20 \mathrm{~m}$ apart, that covered the whole area of the cove, making sure that the visual field of divers overlapped. Dives were made daily in the morning for three hours. A total of 2590 conchs were marked through the four years of study. All captured organisms were taken to the side of the cove, in order to be marked with a nylon ribbon with a plastic identification tag fasten to the spire, and measured in shell length with a fish measuring board; lip thickness was measured with a vernier caliper $(0.1 \mathrm{~mm}$ precision $)$, and the total live weight was obtained with an mechanic plate scale with $0.1 \mathrm{~g}$ precision. All animals were released in the same location where they were found.

During successive recaptures only unmarked organisms were marked, and all of them were measured and registered. The number of organisms within Xel-Ha was estimated by the Jolly's method for multiple recaptures (Poole, 1974). Increments in shell length, weight and lip thickness were analyzed using Appeldoorn's subroutines of the FISAT II program (Gayanilo \& Pauly, 1997) to estimate the basic parameters of the Von Bertalanffy, for juveniles (conchs without a flare lip), adults (conchs with a flare lip) and the whole population. Once the five basic parameters of the seasonalized Von Bertalanffy equation (Equation 1) ( L $\infty, \mathrm{K}, \mathrm{T}_{0}, \mathrm{C}$ and $\mathrm{Wp}$ ) were estimated for each group, size frequency tables were generated and used to run FISAT II recruitment and mortality subroutines. Mortality was estimated with the "length converted catch curve" subroutine.

$$
\begin{gathered}
L_{t}=L_{\infty}\left(1-e^{\left(-K\left(t-t_{0}\right)+S t_{s}+S t_{0}\right)}\right) \\
S t_{0}=(C K / 2 \pi) \times \sin \left(2 \pi\left(t_{0}-t_{s}\right)\right. \\
S t_{\mathrm{s}}=(C K / 2 \pi) \times \sin \left(2 \pi\left(\mathrm{t}-\mathrm{t}_{\mathrm{s}}\right)\right) \\
T_{s}=0.5+W P
\end{gathered}
$$

Where:

$\mathrm{Lt}$ is the length at time $\mathrm{t} ; \mathrm{L} \infty$ the maximum hypothetical length expressed by the asymptote of the growth curve; $t_{0}$ the time when the growth function starts; $\mathrm{C}$ is the intensity of cessation of growth; during summer $\left(\mathrm{St}_{\mathrm{s}}\right)$ and winter $\left(\mathrm{St}_{0}\right)$; WP is the time of the year of the lowest growth.

\section{RESULTS}

Water quality: Temperature, salinity and dissolved oxygen fluctuations of bottom waters found through the studied years for La Bocana, Centro and La Cueva are presented in table 1.

Bottom water temperatures varied over the range of 12.9 to $29.4^{\circ} \mathrm{C}$ in all three sampling sections. Mean temperature for La Cueva was $21.6^{\circ} \mathrm{C}, 19^{\circ} \mathrm{C}$ for Centro and $28.2^{\circ} \mathrm{C}$ in La Bocana.

The highest bottom salinity was registered during April 2002 with 35PSU in la Bocana, and the minimum during April 2003, with 10PSU in la Cueva. Salinity at Centro was generally lower than in La Bocana, but higher than La Cueva, with the exception of higher precipitation months that resulted lower. 
TABLE 1

Bottom water quality parameters taken at La Bocana, Centro and La Cueva of Xel-Ha cove, Quintana Roo, Mexico

\begin{tabular}{lccccccccc} 
& \multicolumn{3}{c}{ BOCANA } & \multicolumn{3}{c}{ CENTRO } & \multicolumn{5}{c}{ CUEVA } \\
\cline { 3 - 3 } & TEMP & PSU & $\mathrm{O}_{2} \mathrm{mg} / \mathrm{L}$ & TEMP & PSU & $\mathrm{O}_{2} \mathrm{mg} / \mathrm{L}$ & TEMP & PSU & $\mathrm{O}_{2} \mathrm{mg} / \mathrm{L}$ \\
FEB & 26.2 & 28.2 & 7.0 & 26.0 & 27.4 & 3.6 & 25.5 & 28.7 & 6.3 \\
MAR & 25.8 & 35.1 & 6.3 & 12.9 & 27.0 & 6.3 & 13.0 & 26.6 & 6.3 \\
APR & 27.0 & 23.5 & 6.9 & 13.2 & 26.8 & 6.8 & 18.1 & 27.9 & 6.6 \\
MAY & 27.6 & 34.8 & 7.2 & 13.7 & 27.6 & 7.0 & 19.1 & 31.4 & 6.9 \\
JUN & 28.5 & 33.0 & 7.3 & 14.2 & 28.5 & 7.2 & 22.0 & 30.5 & 7.1 \\
JUL & 29.1 & 29.5 & 6.3 & 14.5 & 28.1 & 6.5 & 24.6 & 26.9 & 6.7 \\
AUG & 29.3 & 27.8 & 7.3 & 15.0 & 29.2 & 7.1 & 22.8 & 29.2 & 7.0 \\
SEP & 29.4 & 30.1 & 6.7 & 15.4 & 29.3 & 6.8 & 21.7 & 29.8 & 6.8 \\
OCT & 29.1 & 30.4 & 5.7 & 22.3 & 29.6 & 6.0 & 23.7 & 30.3 & 6.3 \\
NOV & 29.0 & 34.2 & 5.6 & 25.6 & 29.1 & 5.8 & 24.7 & 29.9 & 5.9 \\
DEC & 29.2 & 33.3 & 3.7 & 27.4 & 28.2 & 4.3 & 26.0 & 29.2 & 4.8 \\
MAX & 27.7 & 27.6 & 6.8 & 27.6 & 29.5 & 6.3 & 18.2 & 27.0 & 5.8 \\
MIN & 29.4 & 35.1 & 7.3 & 27.6 & 29.6 & 7.2 & 26.0 & 31.4 & 7.1 \\
MEAN & 25.8 & 23.5 & 3.7 & 12.9 & 26.8 & 3.6 & 13.0 & 26.6 & 4.8 \\
\hline
\end{tabular}

The highest oxygen concentration value was recorded during March 2002 with $7.8 \mathrm{mg} / \mathrm{L}$ in La Bocana, where oxygen concentration was always higher than for the other two sections. The lowest concentration was registered at Centro $3.6 \mathrm{mg} / \mathrm{L}$.

Population size variations: The number of sampled organisms and estimated total numbers from the mark-recapture data after the density Jolly's analysis are presented in table 2. Our data shows that this population of queen conch fluctuates from a minimum of 49 to a maximum of 9848 conchs. The lowest number of conchs were found during March and April, 2003 (67 and 49, respectively), while the maximum densities were found during July and December 2002 (1 741 and 4 652, respectively) and June, 2005 (9 848) (Fig. 2).

Population structure: For the whole population, the best fit of the Von Bertalanffy equation was attained with weight (Fig. 3). For the juvenile fraction of the population, the best fit of the Von Bertalanffy equation was accomplished with shell length (Fig. 4); and for the adult fraction, it was achieved with lip thickness (Fig. 5). The accumulated size structure

TABLE 2

Von Bertalanffy growth parameters for Strombus gigas without flare lip and with flare lip from Xel-Ha Park

\begin{tabular}{lccccccccc} 
& $\mathrm{L} 1 \mathrm{Mm}$ & $\mathrm{Se}$ R2 & $\mathrm{L} 2 \mathrm{~mm}$ & $* \mathrm{Se} * * \mathrm{R} 2$ & $\mathrm{Wg}$ & $*$ Se **R2 & Lth $\mathrm{mm}$ & $* \mathrm{Se} * * \mathrm{R} 2$ \\
$\mathrm{~L} \infty$ & 251 & $* 12.38$ & 330 & $* 55.91$ & 3850 & $* 231.60$ & 47.78 & $* 2.69$ \\
$\mathrm{~K}$ & 0.3 & $* 0.06$ & 0.07 & $* 0.02$ & 0.36 & $* 0.04$ & 0.17 & $* 0.08$ \\
$\mathrm{Wp}$ & 0.3 & $* 0.05$ & 0.5 & $* 0.06$ & 0.3 & $* 0.08$ & 0.5 & $* 0.09$ \\
$\mathrm{C}$ & 0.8 & $* 0.03$ & 0.5 & $* 0.03$ & 0.8 & $* 0.13$ & 0.3 & $* 0.06$ \\
$\mathrm{Z}$ & 0.49 & $* * 0.95$ & 0.72 & $* * 0.92$ & 0.55 & $* * 0.94$ & 0.29 & $* * 0.97$ \\
$\mathrm{~T}_{0}$ & -0.4 & & -0.8 & & -0.8 & & -0.48 & \\
\hline
\end{tabular}

L1, length for juveniles; L2, length for adults; W, weight for the whole population; Lth, lip thickness for adults; *Se, Standard error; **R2, Correlation index. L $\infty, \mathrm{K}, \mathrm{Wp}, \mathrm{C}, \mathrm{T}_{0}$ seasonalized Von Bertalanffy equation parameters, $\mathrm{Z}$, total mortality. 


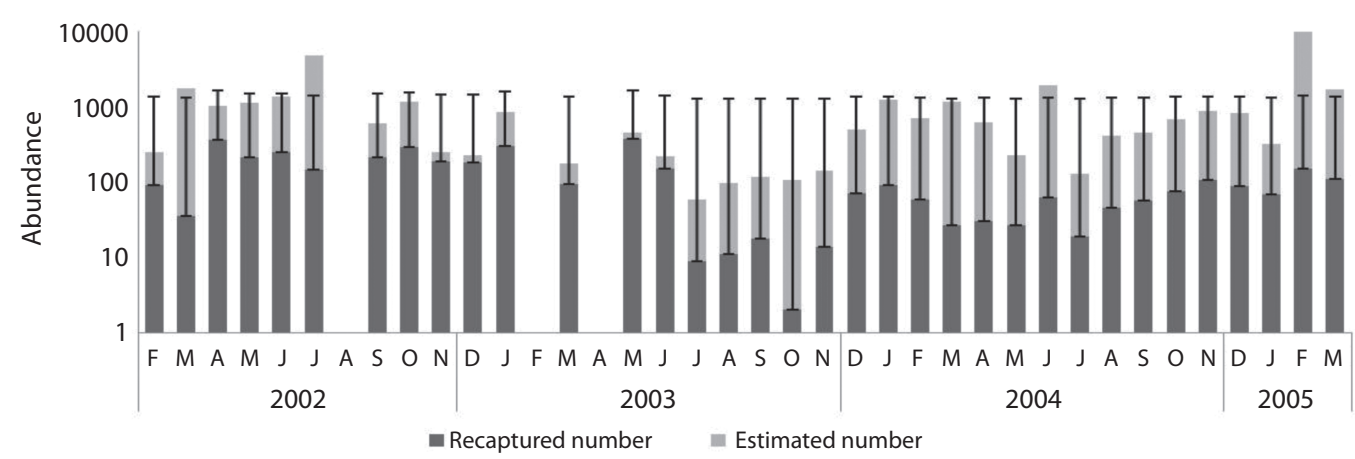

Fig. 2. Number of organisms captured (dark bars) during sampling and the estimated total number (clear bars) of Strombus gigas population in the marine protected area of Xel-Ha Park, Quintana Roo, Mexico. Standard deviation is presented with solid lines.

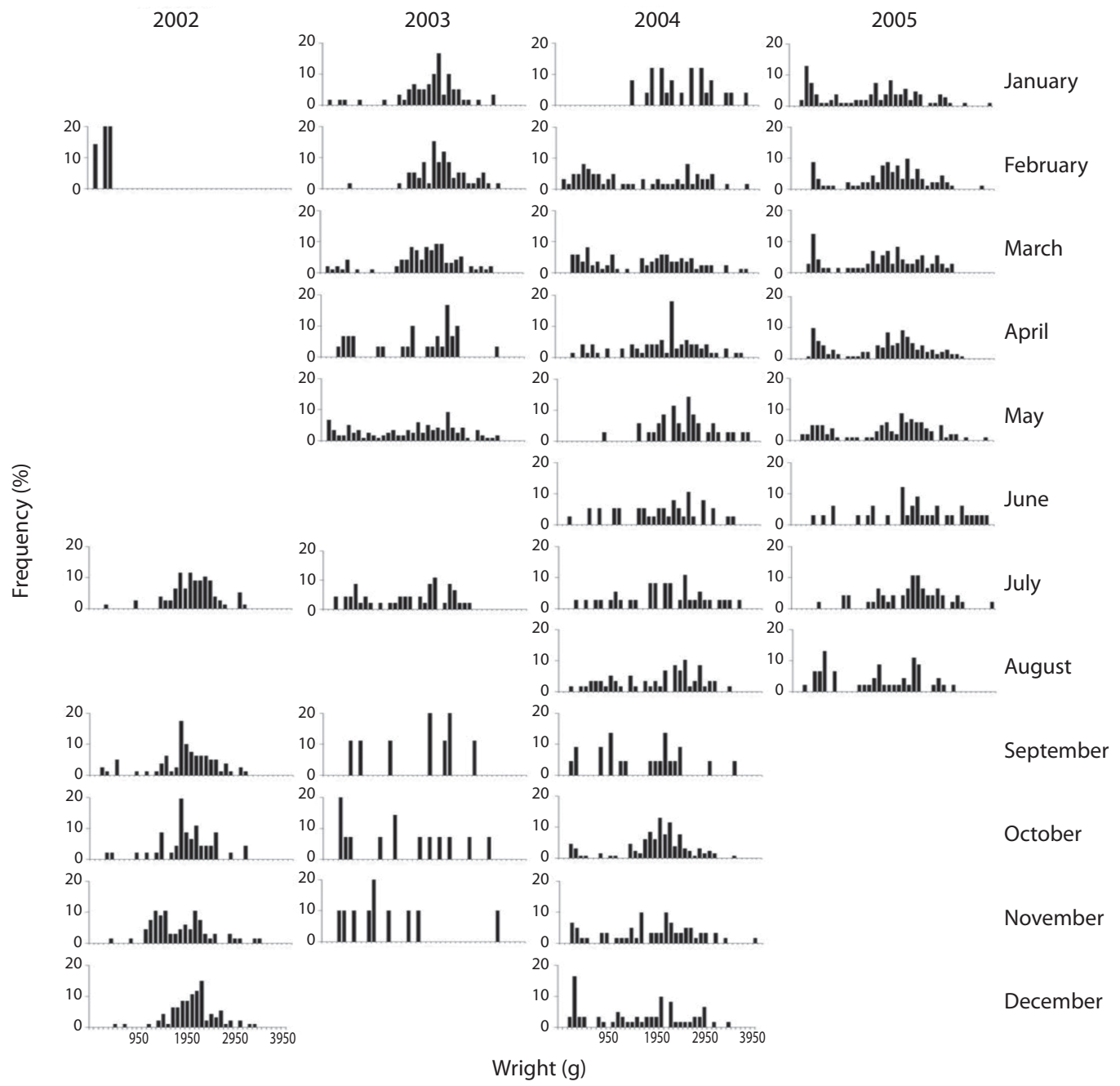

Fig. 3. Monthly variations within the population structure for weight for the whole population of Strombus gigas from XelHa Park, Mexico. 


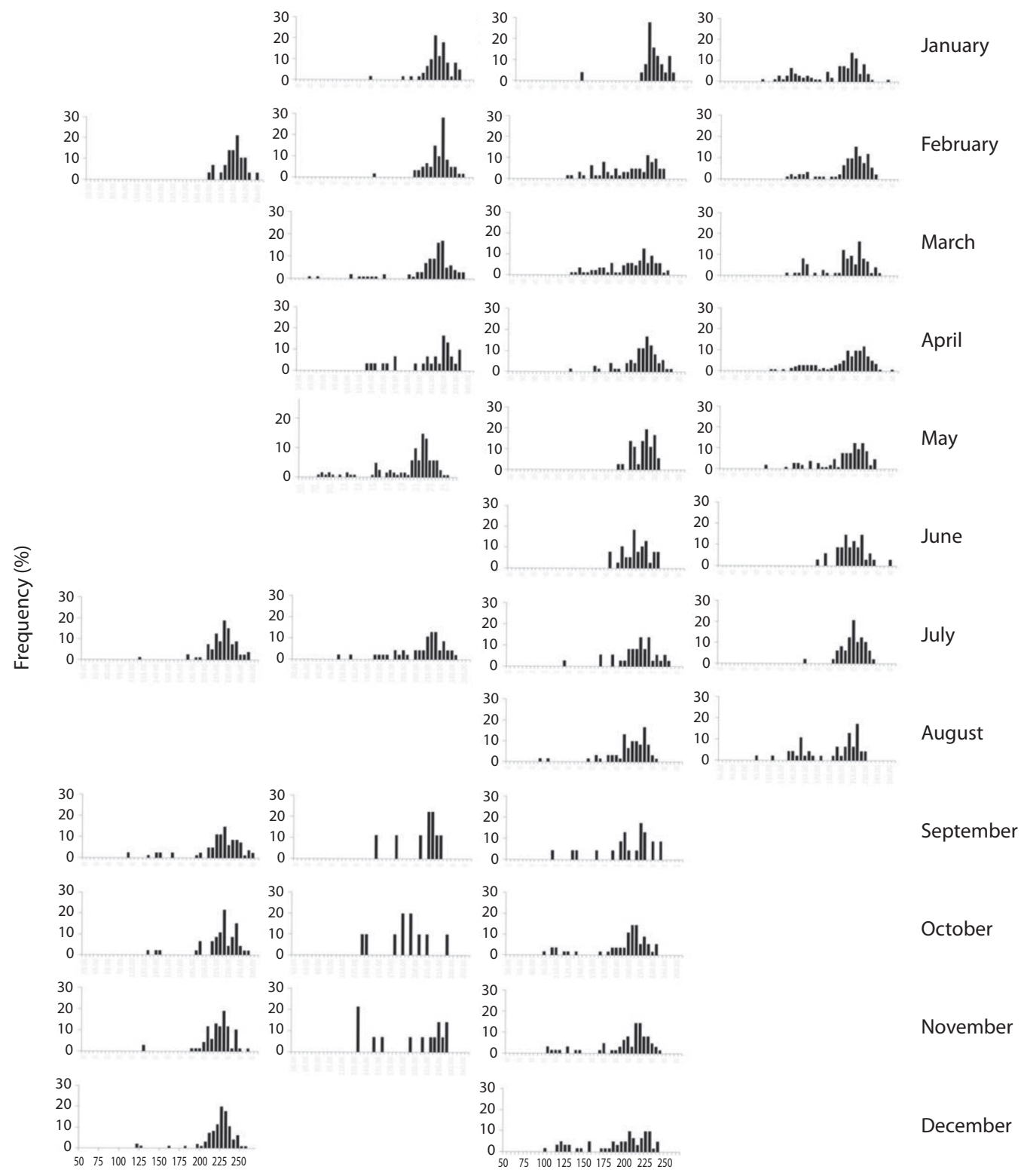

Shell length $(\mathrm{mm})$

Fig. 4. Monthly variations within the population structure for shell length for the whole population of Strombus gigas from Xel-Ha Park, Mexico. 


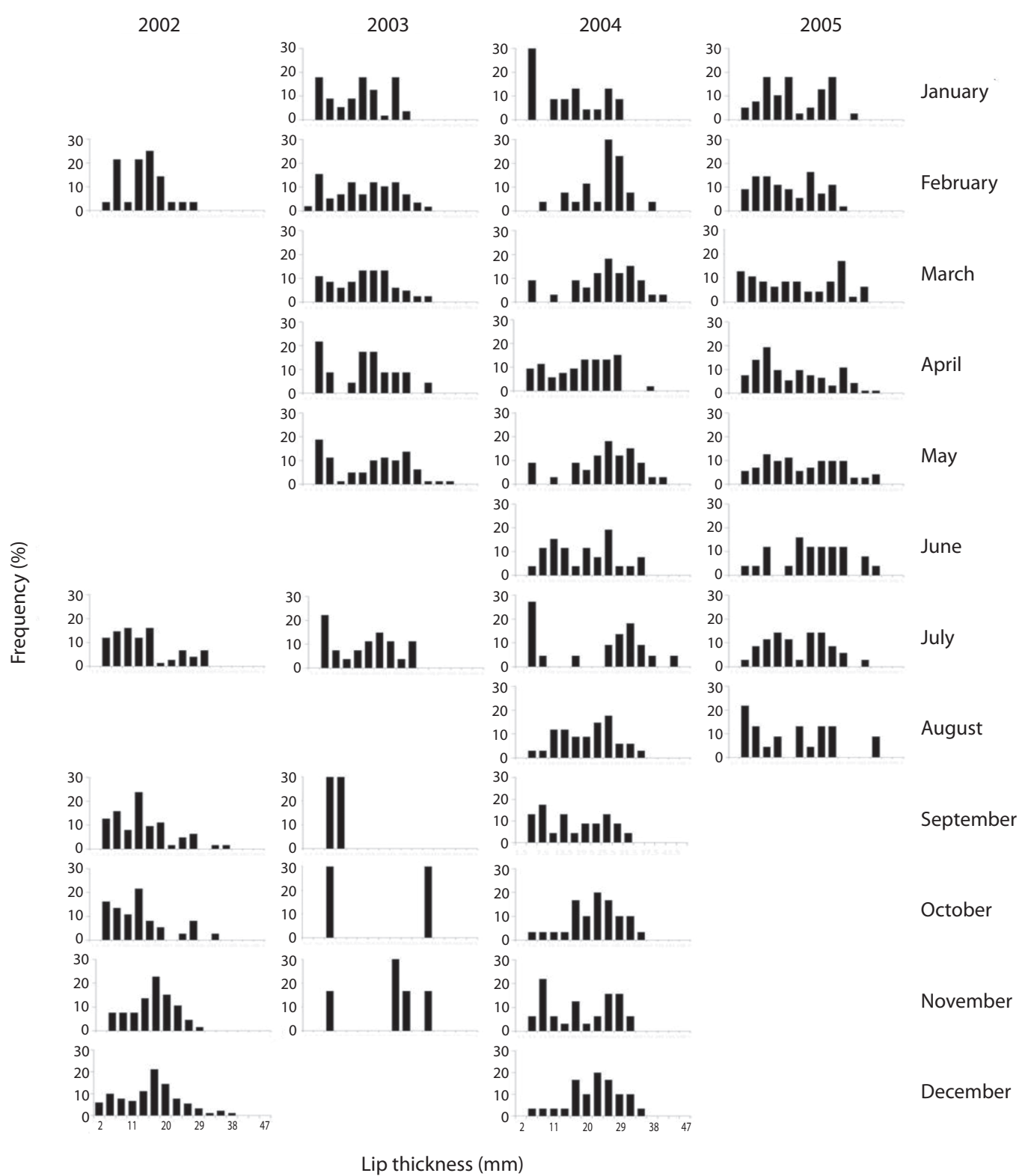

Fig. 5. Monthly variations within the population structure for lip thickness for the adult population of Strombus gigas from Xel-Ha Park, Mexico.

from shell length, live weight and lip thickness are presented in figure 6 , their corresponding modal progression analyses, which present the number of cohort components are presented in figure 7.

From the length frequency distribution, the juveniles presented a poly-modal distribution with a mean of $179 \mathrm{~mm}$ (Fig. 6a and 7a), while the adult fraction was unimodal with a mean of $220 \mathrm{~mm}$ and a dominant class of $222.5 \mathrm{~mm}$ (Fig. 6a and 7b). The mean length for the whole population was $209 \mathrm{~mm}$ (Fig. 6a). The modal progression analysis identified only three components for the entire population (Fig. 7a) and 

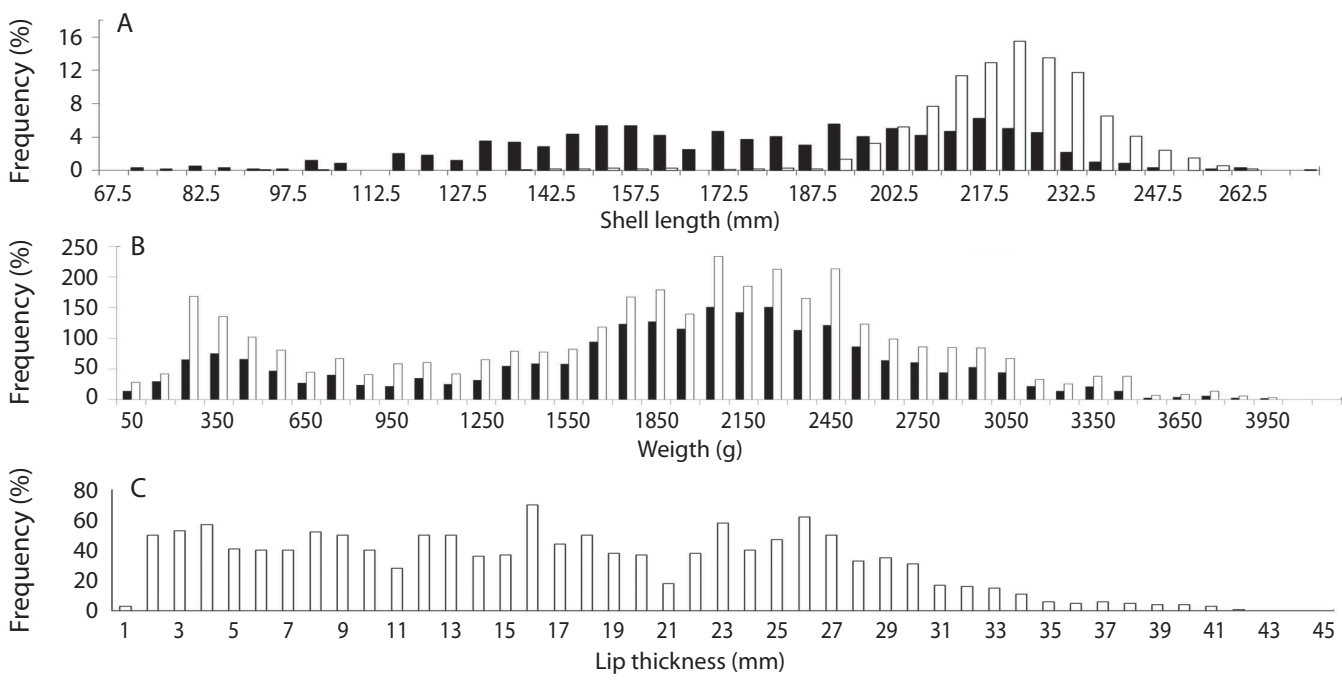

Fig. 6. Accumulated population structure of Strombus gigas from Xel-Ha park, Mexico. A, shell length; B, weight; C, lip thickness. Solid bars for the juvenile fraction of the population. Clear bars for adults.

one for the adult fraction, conchs with flare lip (Fig. 7b), while the analysis of the juvenile fraction identified eight components (Fig. 7c).

The weight distribution histogram shows a total overlap of both groups (Fig. 6b) made up of ten cohorts (Fig 7d). Maximum weight for adult conchs was $3930 \mathrm{~g}$, with a mean of 2 235g. Besides, juvenile conchs reached a maximum weight of $3055 \mathrm{~g}$ with a mean of 1 $882 \mathrm{~g}$. Mean weight for the whole population was $2058 \mathrm{~g}$.

Lip thickness frequency distribution (Fig. 6c) shows a poly-modal distribution with four components (Fig. 7e), with a mean of $15.7 \mathrm{~mm}$, maximum of $41 \mathrm{~mm}$ and minimum of $0.4 \mathrm{~mm}$.

\section{Growth equations and age estima-} tes: The Von Bertalanffy growth parameters estimated from shell length, weight and lip thickness are given in table 3. For juveniles and adults, two different equations have been estimated from shell length; weight was estimated for the whole population and lip thickness for adults only. The four equations presented a better fit when seasonalized. All of them presented similar periods of growth cessation ( $\mathrm{Wp}=0.3$ and 0.5 ). Cessation of growth in juveniles, analyzed through shell length, and for the whole population, analyzed through weight, was high $(\mathrm{C}=0.8)$. The adult cessation of growth obtained from shell length was $\mathrm{C}=$ 0.5 , and from lip thickness was $\mathrm{C}=0.1$.

The estimated maximum age from shell length for adults was of 15 years, which added to the mean four year age for juveniles, give a total age of 19 years. On the other hand,

TABLE 3

Reported growth parameters of the Von Bertalanffy equation of Strombus. gigas from different localities at Quintana Roo, Mexico, for exploited populations. $\mathrm{L} \infty, \mathrm{K}$ and $\mathrm{T}_{0}$ von Bertalanffy growth curve parameters

\begin{tabular}{lccccl}
\multicolumn{1}{c}{ Locality } & $\mathrm{L}_{\infty} \mathrm{mm}$ & $\mathrm{K}$ & $\mathrm{T}_{0}$ Years & Maximum Age & \multicolumn{1}{c}{ Author } \\
Banco Chinchorro & 283.5 & 0.4 & -0.74 & 9 & Castro de Anda, 1994 \\
Punta Gavilán & 293.8 & 0.27 & -0.53 & 11 & De Jesús Navarrete et al., 1999 \\
Banco Chinchorro & 297.8 & 0.3 & 0.002 & 8 & Cruz et al., 1994 \\
Mahahual & 227 & 0.036 & - & $>20$ & Díaz, 1991 \\
\hline
\end{tabular}



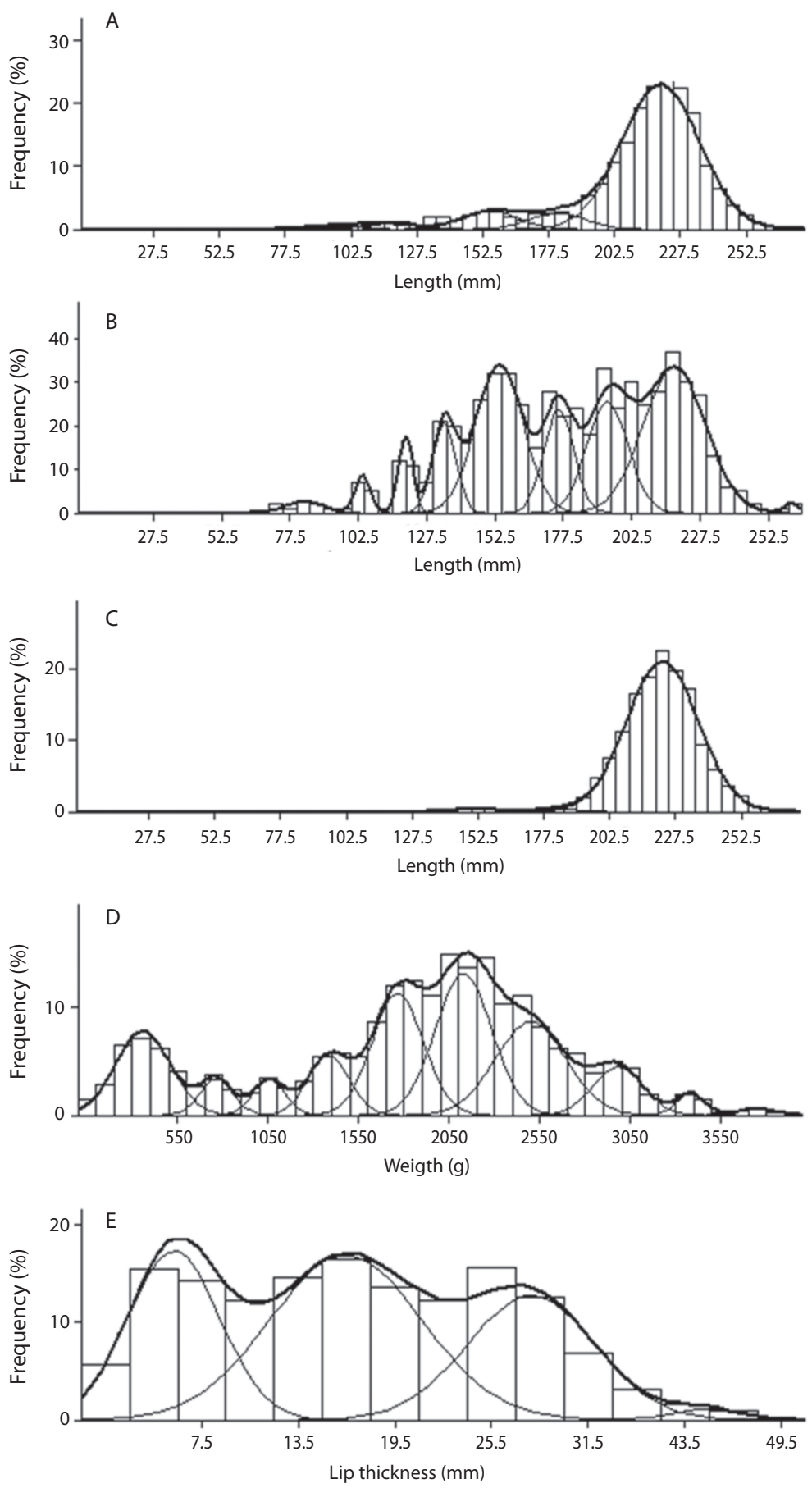

Fig. 7. Modal progression analysis. A, Shell length for the whole population; B, Shell length of juveniles; C, Shell length for adults; D, live weight for the whole population and E, lip thickness for adults. 
growth parameters from weight for the whole population gave a maximum age of 11 years, which was reflected on the modal progression analysis, where only seven years were identified. The growth equation estimated from lip thickness gave an age composition of 14 years, which added to the four years for lip formation, gave a total age of 18 years.

Recruitment pattern: Recruitment can be inferred from the size frequency distribution histograms from the presence of the smallest classes (Fig. 3, 4 and 5), where a constant recruitment is observed with two pulses: January to April and June to August. The smallest organism found was $12 \mathrm{~g}$ (103mm) included in class of $50 \mathrm{~g}$. Recruitment patterns estimated by the FISAT program showed very different trends (Fig. 8). The best fits for the observed data were given by the parameters from lip thickness (Fig. 6d), which showed a constant recruitment with two pulses.

Mortality: Mortality “Z” was estimated separately for the juvenile and adult fractions
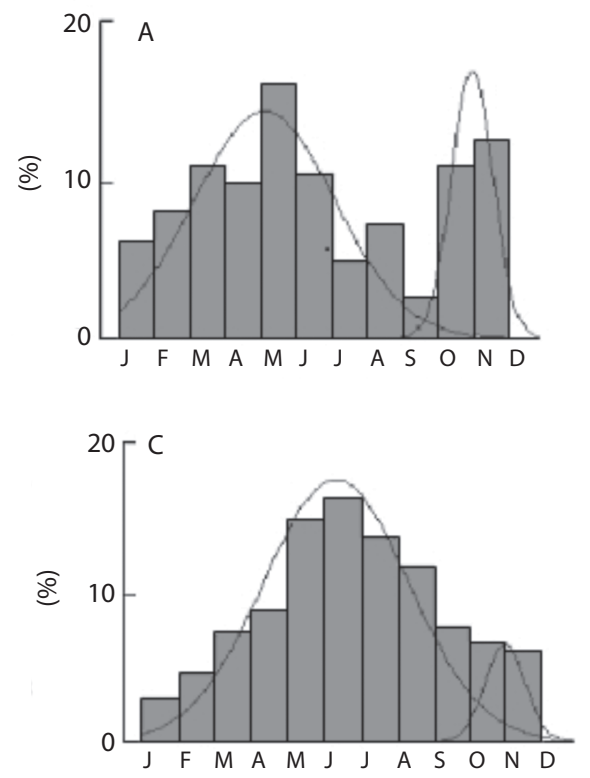

of the population from total shell length. Mortality for juveniles was 0.49 /year, and for the adult estimated from lip thickness was 0.29/ year (Table 2).

\section{DISCUSSION}

This study was undertaken without considering the analysis of the effect of environmental conditions on the conch population, but only to estimate the variations on the population structure and its growth parameters within the cove. Nevertheless, after the first years of the study, we realized that there was a tendency of juveniles to migrate towards the inner cove ( $\mathrm{La}$ Cueva), where, opposed to what was expected, bottom salinity was similar to the values found in la Bocana. This resulted different from the Centro section, where salinity, temperature and oxygen concentrations were lower. This condition may be explained by the runoff from the Northern canal of the cove, where no conchs were found. Temperature at la Cueva differed markedly from the outer cove, La Bocana.
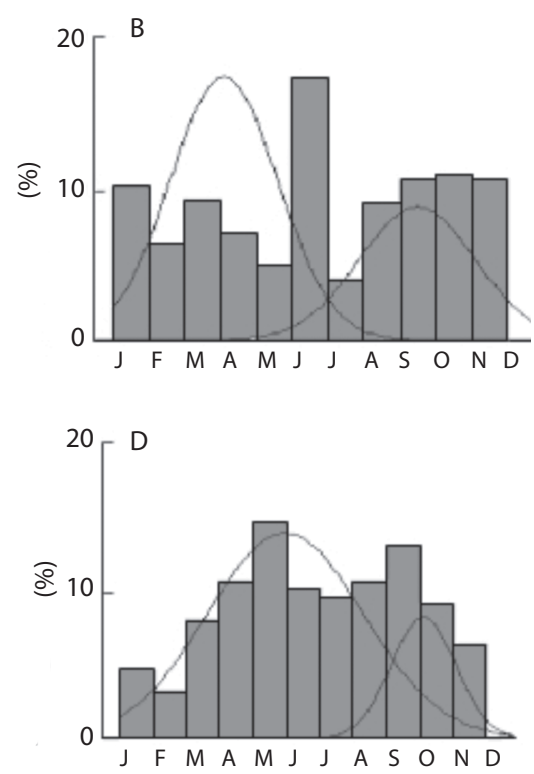

Fig. 8. Recruitment patterns for Strombus gigas Xel-Ha population, estimated for the different parameters. A, Shell length for juveniles; B, Shell length for adults; C, Live weight for the whole population;D, lip thickness for adults. Bars represent the percentage of recruitment. Lines are an estimate of normal distribution for two components. Values of the Von Bertalanffy equation from growth increments used for estimations are given in table 3 . 
The population in this study was treated as a whole and the migratory patterns and effects of environmental conditions will be analysed on a later contribution.

The dominance of juveniles $(78 \%)$ over adult organisms $(22 \%)$, the very low recapture rate, and the mean number of three successive months that organisms were recaptured, suggested that conchs enter the Xel-Ha cove as juveniles, and have a maximum residence time from one to two years. The low numbers occasionally found, may be explained by the burrowing habit during storms (Hesse, 1979; Stoner \& Sandt 1992), which could have skewed to under estimate the population size.

Lip thickness is a measure of growth once shell length ceases, and it can be registered in conchs once they have attained sexual maturity (Appeldoorn, 1994b). It is generally accepted that maturity is attained in the fourth year (Alcolado, 1976; Appeldoorn, 1994b). Stoner \& Glazer (1998) gave mortality rates for $100 \mathrm{~mm}$ conchs without flared lip of 0.5 to 12 , and for conchs of $200 \mathrm{~mm}$ from 2 to 12 . These authors associated high mortality rates to anomalous behavior and shell shape correlated with hatchery rearing. Lara Peréz-Soto (1992) reported for juvenile's mortality rates of 0.23 to 0.54 and for adults of 0.55 to 0.75 for a population subject to commercial fishing. Juvenile's mortality in this work $(0.49)$ coincides with estimates made by Lara Peréz-Soto (1992). Given that mortality estimates in this work were obtained from a non catch population, these data can be accepted as natural mortality for juveniles (0.49) and 0.29 as natural morality of the adult population. Given the absence of dead shells within the cove, it is presumed that mortality should be interpreted as emigration.

The maximum age of conchs coincides with the time Xel-Ha Park has been actively promoting the protection of Strombus gigas. Maximum age mean from different authors fluctuates from eight to nine years, which could be a result of fishing activity on those populations, or that these authors have under estimated age. Growth parameters for different localities on the coast of Quintana Roo,
Mexico, present a larger maximum shell length $(\mathrm{L} \infty=297 \mathrm{~mm})$, and higher growth rate $(\mathrm{K}=4)$ (Castro de Anda, 1994; Cruz, Basurto, Martinez, Cadena \& Fanjul, 1994; Díaz, 1991; De Jesús Navarrete, 2001), except for the locality of Mahahual, where Díaz (1991) reported for a juvenile population with a $\mathrm{L} \infty=227 \mathrm{~mm}$, but much lower growth rate $(\mathrm{K}=0.036)$. This may suggest that Xel-Ha cove does not fulfill the optimum conditions for growth. Total age estimated by the Von Bertalanffy equation may give a larger number of age classes than those estimated by a modal progression analysis At the older age classes they can be superimposed and masked, this is frequent on the older conchs where growth increments are small and if the shell becomes eroded they can even appear as having lost weight.

The absence of dead shells within the cove, suggested that the mortality obtained could be interpreted as migration; this condition, together with the maximum estimated age obtained, allowed us to presume that the cove is actively protecting this conch population from the adjacent reef.

The marked differences attained from the variables used for juveniles, adults and the whole populations, emphasize the need to use the correct variable for each size group. Juvenile's growth parameters should be estimated from length frequency data, whereas for adults, growth parameters should be estimated from lip thickness, and when the study covers the whole size range, weight frequency analysis should be used.

\section{ACKNOWLEDGMENTS}

The authors wish to express their gratitude to the Xel-Ha park executive manager for the financial and logistical support and to the personnel of the sustainable development department for their assistance in the field work. This project was supported by the Biology and Aquaculture of Mollusk laboratory of CINVESTAV and grant: CONACyT 24210 connectivity of the Queen Conch in the Caribbean. We want to express our gratitude to 
Gemma Franklin, native English speaker for the review of the manuscript.

\section{RESUMEN}

Parámetros de crecimiento y variaciones de densidad de una población de Strombus gigas (Neotaenioglossa: Strombidae), del parque Xel-Ha área natural protegida. El caracol reina, Strombus gigas, es un gasterópodo de importancia comercial en el Caribe. Los estudios poblacionales se basan en el análisis de las fluctuaciones de las frecuencias de tallas, usando ya sea la longitud de la concha o el peso total de los organismos vivos. Este aporte usa datos de marcaje recaptura para estimar los parámetros de la ecuación de Von Bertalanffy y variaciones en el número de la población, para una población sin captura dentro de un área protegida, para aclarar que parámetros se adaptan mejor para estudios de la población entera o para las fracciones de juveniles y adultos por separado. Se muestrearon mensualmente, caracoles del parque Xel-Ha, de Noviembre 2001 a Agosto 2005. Todas las conchas encontradas se se midieron y marcaron con una etiqueta numerada que identificó la fecha de muestréo y la localidad. Las variaciones en abundancia mensual se estimó con el método de Jolly. Se emplearon la longitud de la concha, el grosor de labio y el peso vivo de los animales para determinar los parámeros de la ecuación de crecimiento de Von Bertalanffy, usando la subrutina de Appeldoorn del programa FISAT. La población varía a lo largo del estudio, con un mínimo de 49 organismos en abril 2003 y un máximo de 9848 durante junio 2005. Los caracoles solo hacen uso temporal de la caleta de Xel-Ha. El mejor ajuste para juveniles se obtuvo con la longitud de la concha: $\mathrm{L} \infty=251, \mathrm{~K}=0.3, \mathrm{C}=0.8 \mathrm{Wp}=0.3$ : mientras que para adultos se obtuvo con el grosor del labio: $\mathrm{L} \infty=47.78, \mathrm{~K}=0.17, \mathrm{C}=0.1, \mathrm{Wp}=0.86$; y la población total se ve mejor representada por el peso: $\mathrm{L} \infty=3850, \mathrm{~K}=0.36$, $\mathrm{C}=0.8, \mathrm{Wp}=0.3$. Se estimó una edad máxima para el total de la población de 19 años. Con mortalidad natural de 0.49 año-1 para juveniles y 0.29 año-1 para adultos. Hubieron dos pulsos de reclutamiento: otoño-invierno y verano. Se concluye que los estudios poblacionales realizados a partir de estructura de tallas, deben de analizar por separado dos grupos o fracciones de la población, usando el peso para juveniles y grosor del labio para adultos, de no ser posible analizar la población por separado, debe de emplearse el peso para evitar una subestimación en la estructura de edad.

Palabras clave: concha, crecimiento, parámetros poblacionales, área marina protegida, Caribe, AMP.

\section{REFERENCES}

Alcolado, P. M. (1976). Crecimiento, variaciones morfológicas de La concha y algunos datos biológicos del cobo Strombus gigas L. (Mollusca, Mesogastropoda). Academia Ciencias Cuba Serie Oceanología, 34-36.

Aldana Aranda, D., Baqueiro Cárdenas, E., \& Manzanilla Naim, S. (2003). Mexican marine parks as a fishery management tool for the queen conch Strombus gigas. In D. Aldana-Aranda (Ed.), El caracol Strombus gigas: conocimiento integral para su manejo sustentable en el Caribe (pp. 101-108). México: CYTED Press.

Appeldoorn, R. S. (1994a). Queen conch management and research: status, needs and priorities. In R. S. Appeldoorn, \& B. Rodríguez (Eds.), Strombus gigas Queen conch biology, fisheries and mariculture (pp. 301-319). Caracas, Venezuela: Fundación Científica Los Roques.

Appeldoorn, R. S. (1994b). Spatial variability in the morphology of Queen Conch and its implications for management regulations. In R. S. Appeldoorn, \& B. Rodríguez (Eds.), Strombus gigas Queen conch biology, fisheries and mariculture (pp. 145-157). Caracas, Venezuela: Fundación Científica Los Roques.

Balán-Dzul, V., \& de Jesús-Navarrete, A. (2011). Densidad, abundancia y estructura poblacional del caracol blanco Strombus costatus en el Caribe Mexicano. Revista de Biología Marina y Oceanografía 46(1), 1-8.

Basurto, M., Cadena, P., Escobedo, G., Fernández, F., \& Figueroa, F. (2005). Evaluación de la población de Strombus gigas en los bancos de Cozumel y Chinchorro y recomendaciones para su aprovechamiento sostenible. Centro Regional de Investigación Pesquera de Puerto Morelos, Quintana Roo. Informe de Investigación.

Castro De Anda, A. (1994). Comparación de tasas de crecimiento del caracol Rosado Strombus gigas Linneaus 1758 en diferentes ambientes del Sur de Quintana Roo. (Tesis de licenciatura). Universidad Autónoma de Baja California, México.

Chávez, E., \& Constanza-Mora, S. (2009). Conceptual Framework for Estimating Annual Quotas in Mexican Queen Conch (Strombus gigas) Fisheries. Proceedings of the Gulf and Caribbean Fisheries Institute, 62, 376-382.

Cruz, D. O., Basurto, M., Martinez, D., Cadena, V., \& Fanjul, R. (1994). Contribución al conocimiento biológico pesquero del caracol rosado, Strombus gigas, en Banco Chinchorro, Quintana Roo, Mexico. Informe Técnico, Centro Regional de Investigación Pesquera, Instituto Nacional de la Pesca, México.

De Jesús Navarrete, A. (2001). Crecimiento del caracol Strombus gigas (Gastropoda: Strombidae) en cuatro ambientes de Quintana Roo, México. Revista Biología Tropical, 49(1): 83-89.

De Jesús-Navarrete, A., Oliva-Rivera, J., Medina-Quej, A., \& Domínguez-Viveros, M. (1999). Crecimiento, reclutamiento y estructura poblacional del caracol 
rosado (Strombus gigas) en punta Gavilán, Quintana Roo, México. Proceedings of the Gulf and Caribbean Fisheries Institute, 46: 74-83.

Diaz, A. C. (1991). Crecimiento y mortalidad de juveniles del caracol rosado Strombus gigas en punta Gavilán, Quintana Roo. Algunas consideraciones sobre el aprovechamiento de su pesquería. Ciencia Pesquera, México 8, 63-70.

FAO. (2009). Conversion factors for processed queen conch to nominal weight. FAO Fisheries and Aquaculture Circular No. 1042.

Gayanilo, F. C., \& Pauly, D. (1997). The FAO-ICLARM Stock Assessment Tools (FISAT). FAO Computerized Information Series. Fisheries, 8, 262.

Hesse, K. O. (1979). Movement and migration of the queen conch, Strombus gigas, in the Turks and Caicos Islands. Bulletin of Marine Science, 29, 303-311.

Lara Pérez-Soto, M. (1992). Tabla de vida y parámetros demográficos de Strombus gigas en Quintana Roo,
México. (Tesis de maestría). Universidad Nacional Autónoma de México, México.

Pérez Pérez, M., \& Aldana Aranda, D. (2000). Distribución, abundancia, densidad y morfometría de Strombus gigas (Mesogasteropoda: Strombidae) en el Arrecife Alacranes, Yucatán, México. Revista Biología Tropical, 48(1), 51-57

Poole, R. W. (1974). An introduction to quantitative ecology. London: Series in Population Biology McGraw Hill.

Stoner, A. W., \& Sandt, V. J. (1992). Population structure, seasonal movements and feeding of queen conch, Strombus gigas, in deep-water habitats of the Bahamas. Bulletin of Marine Science, 5, 287-300.

Stoner, A. W., \& Glazer, R. A. (1998). Variation in natural mortality: implications for queen conch marine stock enhancement. Bulletin of Marine Science, 62, 427-442. 
